\title{
Effects of exogenous hydrogen sulphide on calcium signalling, background (TASK) $K$ channel activity and mitochondrial function in chemoreceptor cells
}

\author{
Keith J. Buckler
}

Received: 16 February 2012 / Accepted: 17 February 2012 / Published online: 15 March 2012

(C) The Author(s) 2012. This article is published with open access at Springerlink.com

\begin{abstract}
It has been proposed that endogenous $\mathrm{H}_{2} \mathrm{~S}$ mediates oxygen sensing in chemoreceptors; this study investigates the mechanisms by which $\mathrm{H}_{2} \mathrm{~S}$ excites carotid body type 1 cells. $\mathrm{H}_{2} \mathrm{~S}$ caused a rapid reversible increase in intracellular calcium with $\mathrm{EC}_{50} \approx 6 \mu \mathrm{M}$. This $\left[\mathrm{Ca}^{2+}\right]_{\mathrm{i}}$ response was abolished in Ca-free Tyrode. In perforated patch current clamp recordings, $\mathrm{H}_{2} \mathrm{~S}$ depolarised type 1 cells from -59 to $-35 \mathrm{mV}$; this was accompanied by a robust increase in $\left[\mathrm{Ca}^{2+}\right]_{\mathrm{i}}$. Voltage clamping at the resting membrane potential abolished the $\mathrm{H}_{2} \mathrm{~S}$-induced rise in $\left[\mathrm{Ca}^{2+}\right]_{\mathrm{i}} \cdot \mathrm{H}_{2} \mathrm{~S}$ inhibited background $\mathrm{K}^{+}$ current in whole cell perforated patch and reduced background $\mathrm{K}^{+}$channel activity in cell-attached patch recordings. It is concluded that $\mathrm{H}_{2} \mathrm{~S}$ excites type 1 cells through the inhibition of background (TASK) potassium channels leading to membrane depolarisation and voltage-gated $\mathrm{Ca}^{2+}$ entry. These effects mimic those of hypoxia. $\mathrm{H}_{2} \mathrm{~S}$ also inhibited mitochondrial function over a similar concentration range as assessed by NADH autofluorescence and measurement of intracellular magnesium (an index of decline in MgATP). Cyanide inhibited background $\mathrm{K}$ channels to a similar extent to $\mathrm{H}_{2} \mathrm{~S}$ and prevented $\mathrm{H}_{2} \mathrm{~S}$ exerting any further influence over channel activity. These data indicate that the effects of $\mathrm{H}_{2} \mathrm{~S}$ on background $\mathrm{K}$ channels are a consequence of inhibition of oxidative phosphorylation. Whilst this does not preclude a role for endogenous $\mathrm{H}_{2} \mathrm{~S}$ in oxygen sensing via the inhibition of cytochrome oxidase, the levels of $\mathrm{H}_{2} \mathrm{~S}$ required raise questions as to the viability of such a mechanism.
\end{abstract}

\footnotetext{
K. J. Buckler $(\square)$

Department of Physiology Anatomy \& Genetics,

University of Oxford,

Parks Road,

Oxford OX1 3PT, UK

e-mail: keith.buckler@dpag.ox.ac.uk
}

Keywords Hydrogen sulphide · Calcium signalling · Chemoreceptors · Mitochondrial function · Oxygen sensing

\section{Introduction}

It has been proposed that hydrogen sulphide is a naturally occurring gassotransmitter similar to nitric oxide [50]. It has also been hypothesised that endogenous $\mathrm{H}_{2} \mathrm{~S}$ production plays a particularly important role in the process of acute oxygen sensing in blood vessels [36, 38], fish gill chemoreceptors [39] and the mammalian carotid body [37, 41]. Endogenous $\mathrm{H}_{2} \mathrm{~S}$ is primarily produced through the metabolism of two sulphur-containing amino acids cysteine and homocysteine by the enzymes cystathionine $\beta$-synthase and cystathionine $\gamma$-lyase ( $\gamma$-cystathionase) $[23,24,26]$. Its subsequent degradation is by oxidation to thiosulphate in the mitochondrion. This occurs in several stages; the first involves the formation of a persulphide with sulphide quinone oxidoreductase (SQR) together with reduction of ubiquinone; this is followed by oxidation of the persulphide by a sulphur dioxygenase to form sulphite; the final reaction is catalysed by a sulphur transferase which produces thiosulphate by transferring a second persulphide from SQR to sulphite [21]. This process requires oxygen for two functions, firstly to re-oxidise ubiqinone via the electron transport chain and secondly in the oxidation of persulphide by sulphur dioxygenase. In the $\mathrm{H}_{2} \mathrm{~S}$ hypothesis, oxygen sensing is proposed to be initiated by alteration of the balance between constitutive $\mathrm{H}_{2} \mathrm{~S}$ production and oxygen-dependent $\mathrm{H}_{2} \mathrm{~S}$ removal [38].

The ability of exogenous $\mathrm{H}_{2} \mathrm{~S}$ to act as a respiratory stimulant has long been recognised, possibly as far back as 
the 1800s [35]. An early contemporary account is given by Hagard and Henderson who, in 1922, reported that both inhalation of $\mathrm{H}_{2} \mathrm{~S}$ gas and injection of $2 \mathrm{mg} / \mathrm{kg} \mathrm{Na}_{2} \mathrm{~S}$ evoked a hyperpnea in dogs [16]. The stimulatory effects of sulphides were subsequently traced to actions upon the carotid body [20]. The mechanisms by which $\mathrm{H}_{2} \mathrm{~S}$ stimulates the carotid body are however largely undefined. It has been reported that chemoreceptor excitation by exogenous $\mathrm{H}_{2} \mathrm{~S}$ can be blocked by removal of external calcium or application of cadmium [31, 41]. This suggests that $\mathrm{H}_{2} \mathrm{~S}$ promotes $\mathrm{Ca}^{2+}$ influx as does hypoxia [6]. It has also been reported that $\mathrm{H}_{2} \mathrm{~S}$ inhibits large conductance $\mathrm{Ca}^{2+}$-activated $\mathrm{K}^{+}$channels $\left(\mathrm{BK}_{\mathrm{Ca}}\right)$ [31]. Inhibition of $\mathrm{BK}_{\mathrm{Ca}}$ alone however is usually insufficient to excite chemoreceptor cells as these channels are inactive under resting conditions [4]. Excitatory responses to hypoxia are primarily mediated by the inhibition of a background potassium current believed to be carried through TWIK-related acid-sensitive potassium (TASK) channels $[4,10,25]$. The effects of $\mathrm{H}_{2} \mathrm{~S}$ on these channels are unknown.

There is also uncertainty in the nature of the signalling pathways linking hydrogen sulphide to modulation of ion channel activity. In blood vessels, $\mathrm{H}_{2} \mathrm{~S}$ has been reported to directly activate $\mathrm{K}_{\mathrm{ATP}}$ channels leading to membrane hyperpolarisation, reduction of voltage-gated $\mathrm{Ca}^{2+}$ influx and vasodilation [56]. $\mathrm{H}_{2} \mathrm{~S}$ has also been reported to inhibit large conductance $\mathrm{Ca}^{2+}$-activated $\mathrm{K}^{+}$ channels $\left(\mathrm{BK}_{\mathrm{Ca}}\right)$ in excised patches [47], again suggesting direct interaction between $\mathrm{H}_{2} \mathrm{~S}$ and the ion channel. $\mathrm{H}_{2} \mathrm{~S}$ is however also a powerful inhibitor of cytochrome oxidase [13]. Indeed, a general criticism of the hypothesised role for $\mathrm{H}_{2} \mathrm{~S}$ as a gasotransmitter is that the majority of studies demonstrating effects of exogenous $\mathrm{H}_{2} \mathrm{~S}$ have employed concentrations that have the potential to poison energy metabolism. This issue is of particular importance when considering a potential role for $\mathrm{H}_{2} \mathrm{~S}$ in oxygen sensing in peripheral chemoreceptors since these organs are sensitive to many inhibitors of oxidative phosphorylation $[2,8,11,20,34,44,54]$. This study therefore seeks to address two main issues in relation to the actions of $\mathrm{H}_{2} \mathrm{~S}$ : (1) how does $\mathrm{H}_{2} \mathrm{~S}$ excite the type 1 cell and are these mechanisms the same as those observed in hypoxia and (2) can the effects of $\mathrm{H}_{2} \mathrm{~S}$ be attributed to a novel signalling pathway or are they simply due to metabolic inhibition.

\section{Methods}

Type 1 cell isolation

Carotid bodies were excised from neonatal rat pups (1115 days) under terminal anaesthesia (2-4\% halothane) in accordance with project and personal licences issued under the UK Animals (Scientific Procedures) Act 1986. Type 1 cells were isolated using enzymatic digestion with $0.3 \mathrm{mg} / \mathrm{ml}$ trypsin (Sigma) and $0.5 \mathrm{mg} / \mathrm{ml}$ collagenase (Worthington) in PBS or Ham's F-12 for $25-30$ min at $35^{\circ} \mathrm{C}$ followed by transfer to enzyme-free culture media (see below) and trituration through fire-polished pipettes. The resultant cell suspension was plated onto poly-L-lysine-coated coverslips and maintained in an incubator at $35^{\circ} \mathrm{C}$ for $2 \mathrm{~h}$ before the addition of further culture media. Cells were used within $8 \mathrm{~h}$ of isolation. Culture media comprised Ham's F-12 or DMEM containing 10\% heat-inactivated foetal bovine serum, $2 \mathrm{mM} \mathrm{L}-$ glutamine and $4 \mu \mathrm{g} / \mathrm{ml}$ insulin.

\section{Measurement of $\left[\mathrm{Ca}^{2+}\right]_{\mathrm{i}},\left[\mathrm{Mg}^{2+}\right]_{\mathrm{i}}$ and NADH}

Fluorescence measurements were performed using a microspectrofluorimeter based on a Nikon Diaphot 200 (Japan) equipped with a xenon lamp to provide an excitation light source and cooled $\left(-20^{\circ} \mathrm{C}\right)$ photomultiplier tubes (Thorn EMI) to detect emitted fluorescence. $\left[\mathrm{Ca}^{2+}\right]_{\mathrm{i}}$ was determined using Indo-1, $\left[\mathrm{Mg}^{2+}\right]_{\mathrm{i}}$ using Mag-Indo-1 and NADH by cellular autofluorescence. Indo-1 and Mag-Indo-1 were loaded into cells by incubation with $2-5 \mu \mathrm{M}$ of the acetoxymethyl ester derivatives of these dyes in culture media at room temperature for $1 \mathrm{~h}$ (Indo-1) or $10 \mathrm{~min}$ (Mag-Indo-1). Indo-1 and Mag-Indo-1 were excited at $340 \mathrm{~nm}$ and fluorescence intensity measured at $405 \pm 16$ and $495 \pm 10 \mathrm{~nm}$. The fluorescence emission ratio (405/495) for Indo-1 was calibrated as previously described [5]; the fluorescence ratio 405/495 for Mag-Indo-1 is presented without calibration. NADH autofluorescence was excited at $340 \mathrm{~nm}$ and emission measured at $450 \pm 30 \mathrm{~nm}$. Data acquisition and analysis was performed using a 1401 interface and Spike 2 software (Cambridge Electronic Design).

\section{Electrophysiology}

Both perforated patch and cell-attached patch recordings were performed using an Axopatch 200B. Electrodes were pulled from borosilicate glass tubing and were sylgarded and fire polished just before use. For perforated patch recording, pipette filling solutions contained (in millimolars) $\mathrm{K}_{2} \mathrm{SO}_{4} 70$, potassium chloride $(\mathrm{KCl}) 30$, ethylene glycol tetraacetic acid (EGTA) 1, (4-(2-hydroxyethyl)-1-piperazineethanesulfonic acid ) (HEPES) 10 and $\mathrm{MgCl}_{2}$ 2, and $\mathrm{pH}$ was adjusted to 7.2 at $37^{\circ} \mathrm{C}$. Amphotericin was added to this solution from a stock solution in DMSO to a final concentration of $120-240 \mu \mathrm{g} / \mathrm{ml}$ just prior to recording. For cell- attached patch recording, pipette filling solutions contained (in millimolars) $\mathrm{KCl} 140, \mathrm{MgCl}_{2}$ 1, EGTA 1, HEPES 10, tetraethylammonium 10, 4-aminopyridine 5. $\mathrm{pH}$ was adjusted to 7.4 at $37^{\circ} \mathrm{C}$. 
Single-channel recordings were performed at a filter frequency of $2 \mathrm{kHz}$, and membrane current was digitised and recorded at 5-20 kHz. Membrane current and voltage during perforated patch recordings were sampled at $5 \mathrm{kHz}$. Data acquisition, voltage clamp control and data analysis were performed using Spike 2 software. Single-channel activity was quantified as NPopen using the main conductance state to set a $50 \%$ opening threshold. Current levels of greater than $150 \%$ of the main conductance state were counted as multiple openings.

Perforated patch recordings were performed with simultaneous measurement of $\left[\mathrm{Ca}^{2+}\right]_{i}$. Cells failing to maintain low resting levels of $\left[\mathrm{Ca}^{2+}\right]_{\mathrm{i}}$ following patch formation and perforation were rejected (see [4]). Whole-cell current-voltage (I/V) relationships were determined by using voltage ramps. In these experiments, average I/V curves (as in Fig. 4c) were constructed by averaging digitised current and voltage data first over $0.5-\mathrm{mV}$ intervals, then over 515 successive ramps and finally $\mathrm{I} / \mathrm{Vs}$ from individual cells were averaged.

It was noted that $\mathrm{H}_{2} \mathrm{~S}$ frequently caused an offset at the reference electrode of between 3 and $10 \mathrm{mV}$. Raw recordings of membrane potential (i.e. Fig. 3a, b) are presented without correction for this offset, but the offset has been corrected for in the summary data presented in the text and Fig. 3c. This error has also been corrected for in recordings of membrane current and current-voltage relationships (Fig. 4). In singlechannel recordings, a second potential source of voltage offset may result from depolarisation of the resting membrane potential in response to $\mathrm{H}_{2} \mathrm{~S}$ or $\mathrm{CN}^{-}$. In these experiments, no explicit correction for change in membrane voltage (or voltage offset) was made (as these channels are voltage insensitive), but single-channel amplitude was determined under each condition from all-points histograms so that thresholds for determining NPopen could be adjusted to take into account any changes in membrane voltage.

\section{Solutions}

Standard bicarbonate-buffered Tyrode solutions contained (in millimolars): $\mathrm{NaCl} 117, \mathrm{KCl} 4.5, \mathrm{CaCl}_{2} 2.5, \mathrm{MgCl}_{2} 1$, $\mathrm{NaHCO}_{3} 23$ and Glucose 11. In $\mathrm{Ca}^{2+}$-free solutions, $\mathrm{CaCl}_{2}$ was omitted and $100 \mu \mathrm{M}$ EGTA was added. Twenty millimolars $\mathrm{K}^{+}$Tyrode contained $20 \mathrm{mM} \mathrm{KCl}$ and $101.5 \mathrm{mM}$ $\mathrm{NaCl}$, all other constituents remained the same. High- $\mathrm{K}^{+}$ low- $\mathrm{Ca}^{2+}$ solutions for cell-attached patch recordings contained (in millimolars) $\mathrm{NaCl} 21.5, \mathrm{KCl} 100, \mathrm{MgCl}_{2} 1$, $\mathrm{NaHCO}_{3} 23$ and Glucose 11. Normoxic solutions were equilibrated $5 \% \mathrm{CO}_{2}$ and $95 \%$ air, hypoxic solutions were equilibrated with $5 \% \mathrm{CO}_{2}$ and $95 \% \mathrm{~N}_{2}\left(P_{\mathrm{O} 2}=2\right.$ Torr); both had a $\mathrm{pH}$ of 7.4 at $37^{\circ} \mathrm{C}$. Note that for solutions containing $\mathrm{CN}^{-}$or NaHS, Tyrodes were bubbled for $>15$ min prior to the addition of these compounds and thereafter maintained under an atmosphere of $5 \% \mathrm{CO}_{2} / 95 \%$ air (i.e. these solutions were not continuously bubbled as both compounds are volatile in their acid form and would be rapidly lost from solution). $\mathrm{NaCN}$ and $\mathrm{NaHS}$ were added from stock solutions freshly prepared just before use. $\mathrm{H}_{2} \mathrm{~S}$ concentration was estimated assuming $\mathrm{pK}_{\mathrm{a}}=6.9$ [46]. Note that different conventions are used in reporting $\mathrm{H}_{2} \mathrm{~S}$ levels; some authors present the amount of the sulphide salt added to solution rather than the resulting concentration of $\mathrm{H}_{2} \mathrm{~S}$. For comparison, in this study, the total NaHS added to solution is approximately four times the quoted $\mathrm{H}_{2} \mathrm{~S}$ concentration. Different values for $\mathrm{pK}_{\mathrm{a}}$ have also been used, e.g. Whitfield et al. [51] employed a pKa of 6.6 for mammalian blood at $37^{\circ} \mathrm{C}$; applying this value for pKa would give $\mathrm{H}_{2} \mathrm{~S}$ concentrations approximately $4 / 7^{\text {ths }}(57 \%)$ of those reported here.

Statistical analysis of data

Values are expressed as mean \pm standard error of mean. Most comparisons were assessed using a two-tailed $t$ test (paired or unpaired as appropriate). Dose-response data for the effects of $\mathrm{H}_{2} \mathrm{~S}$ on intracellular calcium, magnesium and $\mathrm{NADH}$ fluorescence were analysed using one-way repeated measures ANOVA or Friedman repeated measures ANOVA on ranks. This was followed by multiple comparisons versus control using the Holm-Sidak method or Dunnett's method, respectively. Standard curves were obtained by fitting the four-parameter logistic curve

$$
\text { Response }=\min +(\max -\min ) /\left(1+\left(\left[\mathrm{H}_{2} \mathrm{~S}\right] / \text { EC50 }\right)^{n}\right)
$$$$
\text { where } n=\text { Hill coefficient }
$$

Significance was assumed at $p<0.05$ for $t$ tests, ANOVA and post hoc comparisons against control using Dunnett's method. For post hoc comparisons using the Holm-Sidak method, values were considered significant when $p<$ the critical level, starting at $p<0.05$. Statistical analysis and curve fitting were carried out using SigmaPlot 11 (Systat Software Inc, Germany) or Excel (Microsoft).

\section{Drugs}

$\mathrm{NaSH}$ and EGTA were from Sigma. Indo-1-AM and MagIndo-1-AM were from Molecular Probes.

\section{Results}

Effects of exogenous $\mathrm{H}_{2} \mathrm{~S}$ on intracellular $\mathrm{Ca}^{2+}$ signalling

Exogenously applied $\mathrm{H}_{2} \mathrm{~S}$ caused an abrupt increase in intracellular calcium $(p<0.001$; Friedman repeated measures ANOVA on ranks) from concentrations of $7.5 \mu \mathrm{M}$ and above (see Fig. 1). This $\left[\mathrm{Ca}^{2+}\right]_{\mathrm{i}}$ response rapidly reversed upon 


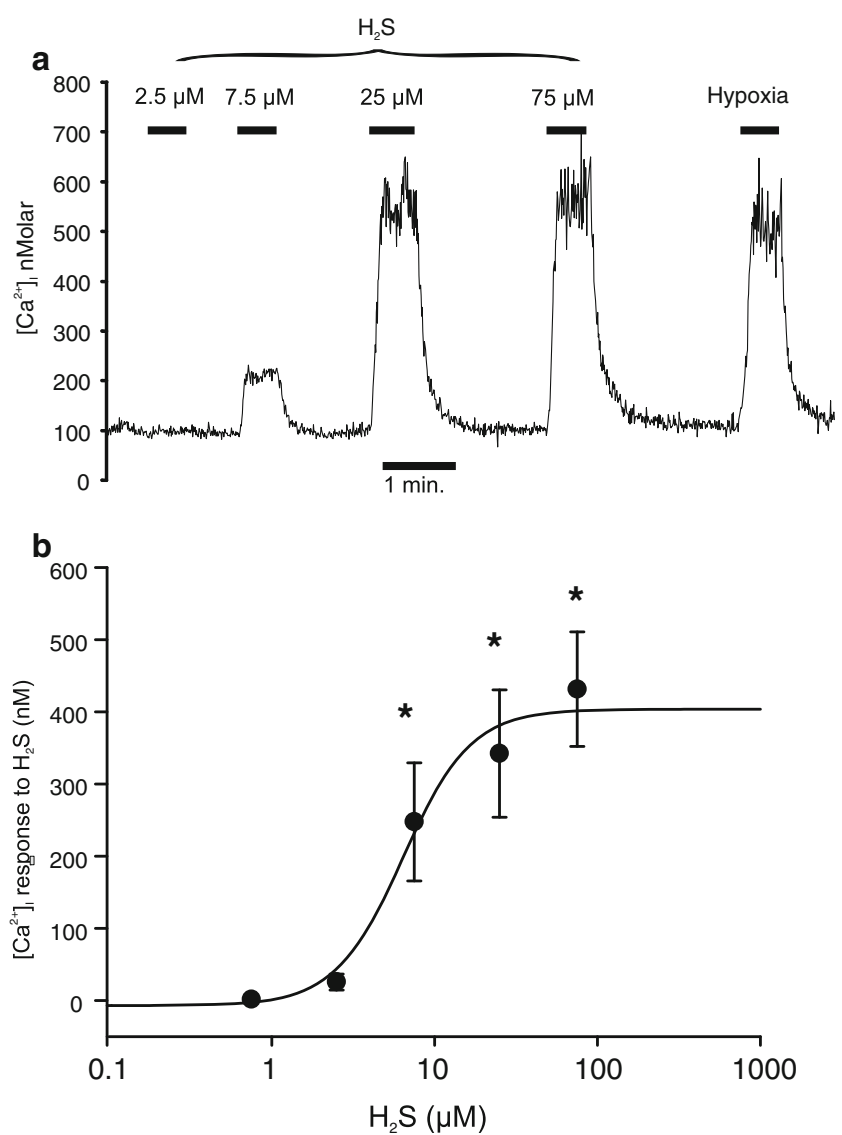

Fig. 1 Effects of $\mathrm{H}_{2} \mathrm{~S}$ on $\left[\mathrm{Ca}^{2+}\right]_{\mathrm{i}}$ in type 1 cells. $\left[\mathrm{Ca}^{2+}\right]_{\mathrm{i}}$ responses to application of graded levels of $\mathrm{H}_{2} \mathrm{~S}$ from 2.5-75 $\mu \mathrm{M}$. a Example of a recording demonstrating rapid rise in $\left[\mathrm{Ca}^{2+}\right]_{\mathrm{i}}$ in response to brief application of $\mathrm{H}_{2} \mathrm{~S}$ at concentrations of $7.5 \mu \mathrm{M}$ and above. Response to a hypoxic stimulus $\left(\mathrm{PO}_{2}=2\right.$ Torr) is also shown for comparison. $\mathbf{b}$ Dose-response relationship for $\mathrm{H}_{2} \mathrm{~S}$-mediated increase in $\left[\mathrm{Ca}^{2+}\right]_{\mathrm{i}}$. Curve is best fit to a four-parameter logistic equation (see "Methods" section) with $\mathrm{EC}_{50}=6 \mu \mathrm{M} .{ }^{*} p<0.05$ (Dunnett's method), $n=8$

removal of $\mathrm{H}_{2} \mathrm{~S}$. The dose-dependent effects of $\mathrm{H}_{2} \mathrm{~S}$ on $\left[\mathrm{Ca}^{2+}\right]_{i}$ were well described by a four-parameter logistic curve (see "Methods" section) with an $\mathrm{EC}_{50}$ of approx $6 \mu \mathrm{M}$ (Fig. 1b).

In order to determine whether the $\mathrm{H}_{2} \mathrm{~S}$-mediated rise in $\left[\mathrm{Ca}^{2+}\right]_{\mathrm{i}}$ was due to $\mathrm{Ca}^{2+}$ influx or $\mathrm{Ca}^{2+}$ release from internal stores, the effects of $25 \mu \mathrm{M} \mathrm{H}_{2} \mathrm{~S}$ were studied in both a normal Tyrode and a Ca-free Tyrode containing $100 \mu \mathrm{M}$ EGTA. In the Ca-free Tyrode, the response to $\mathrm{H}_{2} \mathrm{~S}$ was, on average, inhibited by $>95 \%$ (Fig. 2). The mean rise in $\left[\mathrm{Ca}^{2+}\right]_{\mathrm{i}}$ in control Tyrode was $524 \pm 81 \mathrm{nM}$, whereas that in Ca-free Tyrode was $15 \pm 4 \mathrm{nM}$. This difference was highly significant $(p<0.001$, $n=7$ ) and provides compelling evidence that $\mathrm{H}_{2} \mathrm{~S}$ causes a substantial $\mathrm{Ca}$ influx in type 1 cells.

Effects of exogenous $\mathrm{H}_{2} \mathrm{~S}$ on membrane potential and background $\mathrm{K}$ currents

Type 1 cells also respond to natural chemostimuli including hypoxia and acidosis with $\mathrm{Ca}$ influx which serves to
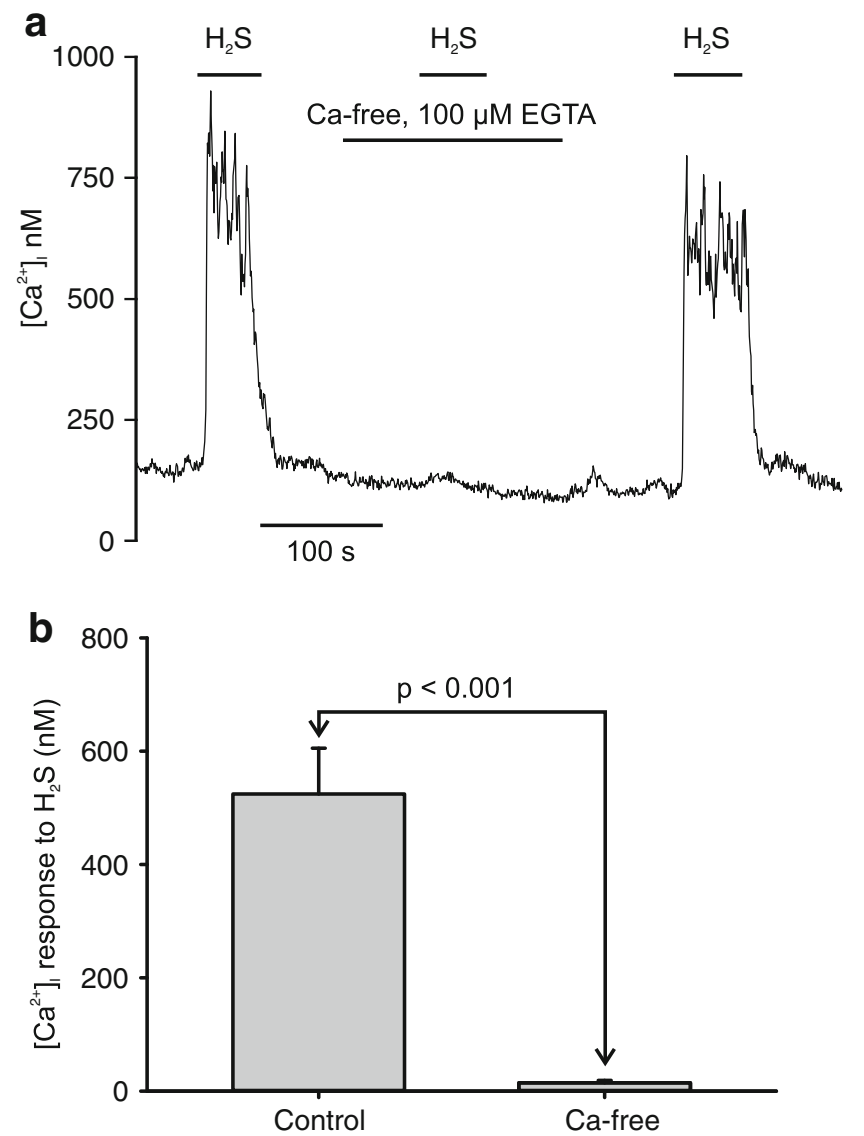

Fig. $2 \mathrm{H}_{2} \mathrm{~S}$ promotes $\mathrm{Ca}^{2+}$ influx. a Effects of $25 \mu \mathrm{M} \mathrm{H}_{2} \mathrm{~S}$ on $\left[\mathrm{Ca}^{2+}\right]_{\mathrm{i}}$ in presence and absence of extracellular $\mathrm{Ca}^{2+} \cdot \mathrm{Ca}^{2+}$-free solutions also contained $100 \mu \mathrm{M}$ EGTA. b Summary of effects of $\mathrm{Ca}^{2+}$-free media (+EGTA) on $\left[\mathrm{Ca}^{2+}\right]_{\mathrm{i}}$ response to $25 \mu \mathrm{M} \mathrm{H}_{2} \mathrm{~S}$. Response was measured as $\left[\mathrm{Ca}^{2+}\right]_{\mathrm{i}}$ during exposure to $\mathrm{H}_{2} \mathrm{~S}-\left[\mathrm{Ca}^{2+}\right]_{\mathrm{i}}$ prior to exposure to $\mathrm{H}_{2} \mathrm{~S}$. $p$ value was determined by paired $t$ test (two tailed), $n=7$

stimulate neurosecretion and thus excitation of afferent nerves. In both of these circumstances, the $\left[\mathrm{Ca}^{2+}\right]_{\mathrm{i}}$ response is mediated by voltage-gated $\mathrm{Ca}$ entry in response to membrane depolarisation and, in many cells, the initiation of repetitive action potentials $[6,7]$. The effects of $\mathrm{H}_{2} \mathrm{~S}$ upon membrane potential were therefore investigated using perforated patch whole cell recording. In this series of experiments, the resting membrane potential of type 1 cells was $-59 \pm 2.0 \mathrm{mV}(n=11)$ under current clamp recording conditions $(\operatorname{Im}=0)$. Following exposure to $25 \mu \mathrm{M}$ $\mathrm{H}_{2} \mathrm{~S}$, all cells depolarised by, on average, approximately $24 \mathrm{mV}$ to a mean potential of $-35 \pm 1.7 \mathrm{mV}(n=11, p<$ 0.001 , Fig. $3 \mathrm{a}-\mathrm{c}$ ). In most cells, this was accompanied by weak electrical activity (e.g. Fig. 3a), although a few cells fired more robust action potentials (e.g. Fig. 3b). This depolarisation was typically rapid in onset (i.e. within $10 \mathrm{~s}$ of application of $\mathrm{H}_{2} \mathrm{~S}$ ) and cells repolarised rapidly following $\mathrm{H}_{2} \mathrm{~S}$ removal. In all instances, $\mathrm{H}_{2} \mathrm{~S}$-induced membrane depolarisation was accompanied by a robust increase in $\left[\mathrm{Ca}^{2+}\right]_{\mathrm{i}}$ from a mean resting level of $109 \pm 14$ to $990 \pm 195 \mathrm{nM}$ in the 

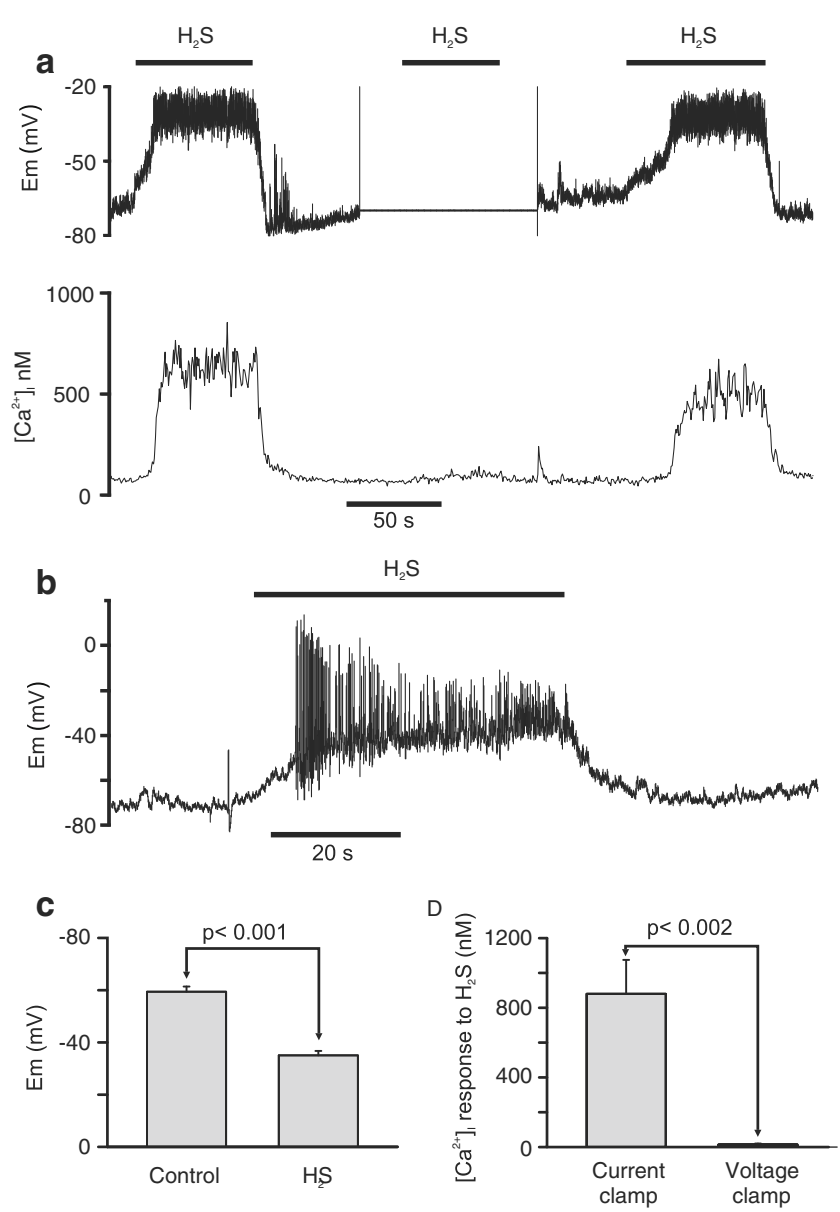

Fig. $3 \mathrm{H}_{2} \mathrm{~S}$ promotes membrane depolarisation and voltage-gated $\mathrm{Ca}^{2+}$ entry. a Simultaneous recording of membrane potential, using the perforated patch technique, and intracellular calcium in a single type 1 cell. Application of $25 \mu \mathrm{M} \mathrm{H}_{2} \mathrm{~S}$ causes a rise in $\left[\mathrm{Ca}^{2+}\right]_{\mathrm{i}}$ coincident with a rapid membrane depolarisation in current clamp $(I=0)$ but little change in $\left[\mathrm{Ca}^{2+}\right]_{\mathrm{i}}$ when the cell is voltage clamped at its resting membrane potential. b Recording of membrane depolarisation in another type 1 cell during exposure to $25 \mu \mathrm{M} \mathrm{H} \mathrm{H}_{2} \mathrm{~S}$ showing action potential generation. c Summary of effects of $25 \mu \mathrm{M} \mathrm{H} \mathrm{H}_{2} \mathrm{~S}$ on average membrane potential in current clamped type 1 cells $(n=11)$. d Summary of effects of voltage clamp on $\left[\mathrm{Ca}^{2+}\right]_{\mathrm{i}}$ response to $25 \mu \mathrm{M} \mathrm{H} \mathrm{H}_{2} \mathrm{~S}$. The $\left[\mathrm{Ca}^{2+}\right]_{\mathrm{i}}$ response was calculated as the difference between baseline $\left[\mathrm{Ca}^{2+}\right]_{i}$ prior to and $\left[\mathrm{Ca}^{2+}\right]_{\mathrm{i}}$ during exposure to $\mathrm{H}_{2} \mathrm{~S}$ under both current clamp and voltage clamp conditions $(n=11)$. $p$ values were determined by paired $t$ test

presence of $\mathrm{H}_{2} \mathrm{~S}(n=11, p<0.002)$. Cells were then placed into voltage clamp with membrane potential held close to the cells' normal resting membrane potential (e.g. Fig. 3a). Under voltage clamp conditions, mean resting $\left[\mathrm{Ca}^{2+}\right]_{\mathrm{i}}$ was $124 \pm 18 \mathrm{nM}$. With membrane potential thus prevented from changing, $\mathrm{H}_{2} \mathrm{~S}$ was applied for a second time during which $\left[\mathrm{Ca}^{2+}\right]_{\mathrm{i}}$ rose only very slightly to $139 \pm 17 \mathrm{nM}$. Voltage clamping the cell thus inhibited the $\mathrm{H}_{2} \mathrm{~S}$-induced rise in $\left[\mathrm{Ca}^{2+}\right]_{\mathrm{i}}$ by, on average, $98 \%(p<0.002, n=11$, see Fig. $3 \mathrm{~d})$. These experiments confirm that the principal cause of the $\mathrm{H}_{2} \mathrm{~S}$ induced rise in $\left[\mathrm{Ca}^{2+}\right]_{i}$ is membrane depolarisation-driven voltage-gated $\mathrm{Ca}^{2+}$ entry as is the case for other chemostimuli (see "Discussion" section).

Effects of $\mathrm{H}_{2} \mathrm{~S}$ on background $\mathrm{K}^{+}$currents and channels

In order to determine the cause of the $\mathrm{H}_{2} \mathrm{~S}$-induced depolarisation, cells were voltage clamped to $-70 \mathrm{mV}$ and subjected to repeated voltage ramps from -100 to $-40 \mathrm{mV}$ at $1 \mathrm{~Hz}$ (see Fig. 4a, b). Application of $25 \mu \mathrm{M} \mathrm{H} \mathrm{H}_{2} \mathrm{~S}$ caused a marked reduction in the membrane current generated in response to these voltage ramps, see Fig. $4 \mathrm{a}$ and compare left and right hand panels of Fig. 4b. Figure 4c shows averaged currentvoltage relationships (I/V) for seven cells in normal Tyrode in the presence and absence of $\mathrm{H}_{2} \mathrm{~S}$. The point at which the control I/V transects the 0 current axis represents the resting membrane potential; note that there is no stable resting membrane potential in this voltage range in the presence of $\mathrm{H}_{2} \mathrm{~S}$ (consistent with the membrane depolarisation recorded in current clamp, see above). The slope of the I/V relationship is also notably less steep in the presence of $\mathrm{H}_{2} \mathrm{~S}$ than under control conditions, indicating that $\mathrm{H}_{2} \mathrm{~S}$ reduces resting membrane conductance. $\mathrm{H}_{2} \mathrm{~S}$ reduced membrane conductance, measured between -55 and $-65 \mathrm{mV}$ by approximately $60 \%$ from $278 \pm 26 \mathrm{pS}$ under control conditions to $106 \pm 22 \mathrm{pS}(p<0.005)$. Cells were then superfused with a high $(20 \mathrm{mM}) \mathrm{K}^{+}$Tyrode and a further set of voltage clamp measurements taken under both control conditions and in the presence of $25 \mu \mathrm{M} \mathrm{H}_{2} \mathrm{~S}$ (see Fig. $4 \mathrm{a}, \mathrm{b}$ and d). $\mathrm{H}_{2} \mathrm{~S}$ also reduced membrane conductance in the high $\mathrm{K}$ tyrode (Fig. 4d). The current-voltage relationship of $\mathrm{H}_{2} \mathrm{~S}$-sensitive current was then calculated both in normal Tyrode and in high $\mathrm{K}$ Tyrode by subtracting the current obtained in the presence of $\mathrm{H}_{2} \mathrm{~S}$ from that obtained under control conditions. This $\mathrm{H}_{2} \mathrm{~S}$-sensitive current is displayed in Fig. 4e. Note that the $\mathrm{H}_{2} \mathrm{~S}$-sensitive current is displaced downward in elevated external potassium. Under control conditions, although the average I/V (from all seven cells) did not show a reversal potential within the voltage range tested, a reversal potential was observed in four cells (between -83 and $-97 \mathrm{mV}$, mean $-90 \pm 3 \mathrm{mV}$ ). In the presence of $20 \mathrm{mM}$ external $\mathrm{K}^{+}$, all seven cells showed a reversal potential (mean $-65 \pm 6 \mathrm{mV}$ ). These reversal potentials are close to the equilibrium potential for potassium ions under these recording conditions ( -94 and $-56 \mathrm{mV}$ for normal and high $\mathrm{K}$ Tyrode, respectively). These data indicate that $\mathrm{H}_{2} \mathrm{~S}$ inhibits a background/resting potassium conductance and that this is probably the primary factor in causing membrane depolarisation.

To confirm the effects of $\mathrm{H}_{2} \mathrm{~S}$ on background $\mathrm{K}^{+}$channels, cell-attached patch recordings were performed. As previously described, by this lab and others, under appropriate recording conditions, there is abundant single-channel activity in these cells at the resting membrane potential from 
Fig. $4 \mathrm{H}_{2} \mathrm{~S}$ inhibits background $\mathrm{K}^{+}$current in type 1 cells. a Perforated patch whole cell voltage clamp recording of membrane current and membrane potential in a type 1 cell exposed to $25 \mu \mathrm{M} \mathrm{H}_{2} \mathrm{~S}$ in both normal Tyrode $\left(4.5 \mathrm{mM}\left[\mathrm{K}^{+}\right]_{\mathrm{o}}\right)$ and high potassium Tyrode $(20 \mathrm{mM}$ $\left[\mathrm{K}^{+}\right]_{\mathrm{o}}$ ). Note small offset in voltage clamp protocol in presence of $\mathrm{H}_{2} \mathrm{~S}$ to correct for the effects of $\mathrm{H}_{2} \mathrm{~S}$ on the reference electrode (see "Methods" section). b Top left trace shows the voltage clamp ramp protocol on a faster time base. Middle and lower traces show membrane current recorded over 3-s intervals in control Tyrode, control Tyrode $+25 \mu \mathrm{M}$ $\mathrm{H}_{2} \mathrm{~S}, 20 \mathrm{mM} \mathrm{K}^{+}$Tyrode and $20 \mathrm{mM} \mathrm{K}^{+}$Tyrode $+25 \mu \mathrm{M} \mathrm{H}_{2} \mathrm{~S}$. These recordings were taken at points $a, b, c$ and $d$ during the recording shown in panel a. Note marked reduction in ramp current during the application of $\mathrm{H}_{2} \mathrm{~S}$. c Average current-voltage relationships obtained from ramp protocols in normal Tyrode with and without $\mathrm{H}_{2} \mathrm{~S}(n=7$ cells). d Average current-voltage relationships obtained from ramp protocols in $20 \mathrm{mM} \mathrm{K}^{+}$ Tyrode with and without $\mathrm{H}_{2} \mathrm{~S}$ ( $n=7$ cells). e $\mathrm{H}_{2} \mathrm{~S}$-sensitive current recorded in normal Tyrode and high $(20 \mathrm{mM}) \mathrm{K}^{+}$Tyrode. $\mathrm{H}_{2} \mathrm{~S}$-sensitive current was determined by subtraction of membrane current recorded in the presence of $\mathrm{H}_{2} \mathrm{~S}$ from that recorded in its absence (control). Note the marked shift in the current-voltage relationship with elevated $\mathrm{K}^{+}$and a reversal potential in $20 \mathrm{mM} \mathrm{K}^{+}$close to the predicted value for $E_{\mathrm{K}}(=-56 \mathrm{mV})$

voltage-insensitive background $\mathrm{K}$ channels which appear to be comprised of members of the TASK-1/TASK-3 channel family, probably predominantly TASK $1 / 3$ heteromers $[10$, 25, 52]. Channel activity (Fig. 5) was recorded at a pipette potential of $+80 \mathrm{mV}$ with the cell bathed in a $100 \mathrm{mM} \mathrm{K}^{+}$and $\mathrm{Ca}$-free Tyrode and with a pipette filling solution containing $140 \mathrm{mM} \mathrm{K}^{+}$and $1 \mathrm{mM} \mathrm{Mg}^{2+}$ (see "Methods" section for full composition). Under these recording conditions, the mean current amplitude of the main conductance state as determined from all-points histograms was $3.4 \pm 0.1 \mathrm{pA}$ (note that the conductance of these channels is dependent upon extracellular $\mathrm{Mg}^{2+}$ concentration; see [52]). The main conductance state was used to set a $50 \%$ threshold for the determination of NPopen. Single-channel activity was approximately halved by $75 \mu \mathrm{M} \mathrm{H}_{2} \mathrm{~S}$ from $0.18 \pm 0.03$ to $0.09 \pm 0.02(n=6 ; p<0.05)$ see Fig. 5.

\section{Effects of $\mathrm{H}_{2} \mathrm{~S}$ on mitochondrial function}

The effects of $\mathrm{H}_{2} \mathrm{~S}$ described above are identical to those of hypoxia (see "Discussion" section); they are also identical to those of many inhibitors of mitochondrial respiration [8, 54]. Since $\mathrm{H}_{2} \mathrm{~S}$ is a well-known inhibitor of cytochrome oxidase [13], this poses the question as to whether the effects of $\mathrm{H}_{2} \mathrm{~S}$ are mediated primarily through the inhibition of oxidative phosphorylation or by some other means. The effects of $\mathrm{H}_{2} \mathrm{~S}$ on mitochondrial function were therefore investigated.

Inhibition of the electron transport chain results in the accumulation of mitochondrial NADH. Since NADH is fluorescent (and NAD is not), changes in NADH levels can be observed by recording cellular autofluorescence (see "Methods" section and [12]). Figure 6a shows a typical

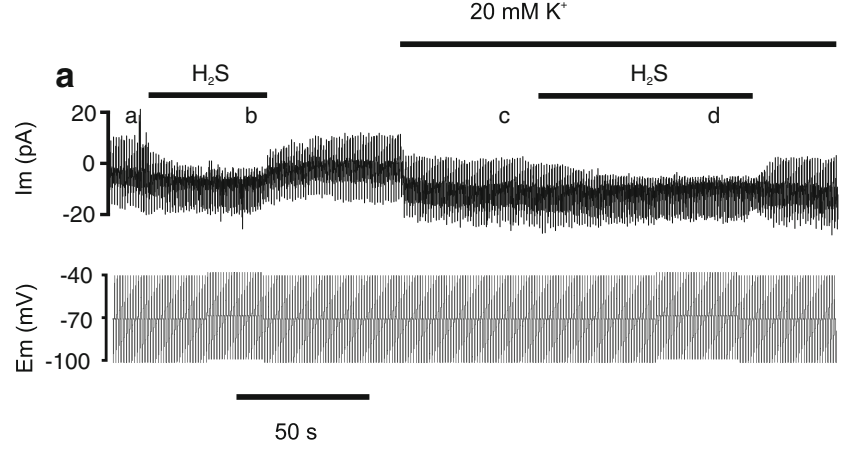

b
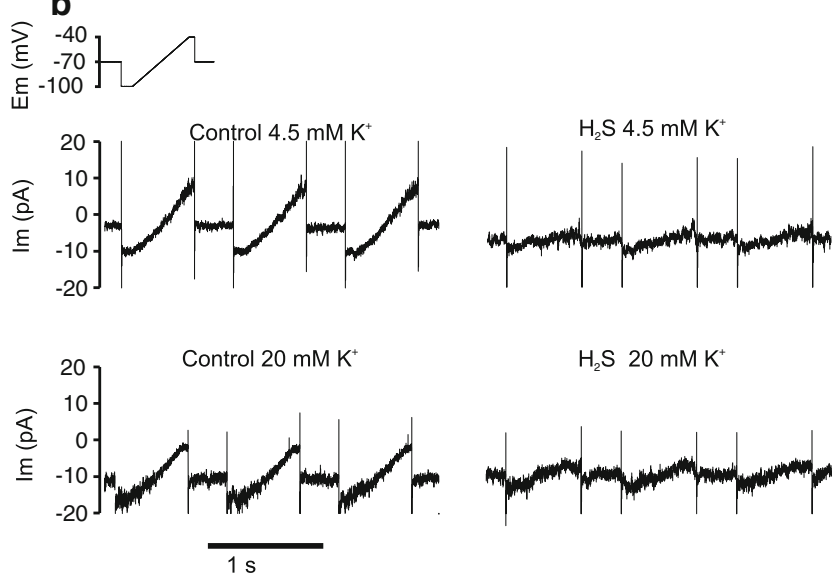

$\mathrm{H}_{2} \mathrm{~S} 20 \mathrm{mM} \mathrm{K}^{+}$
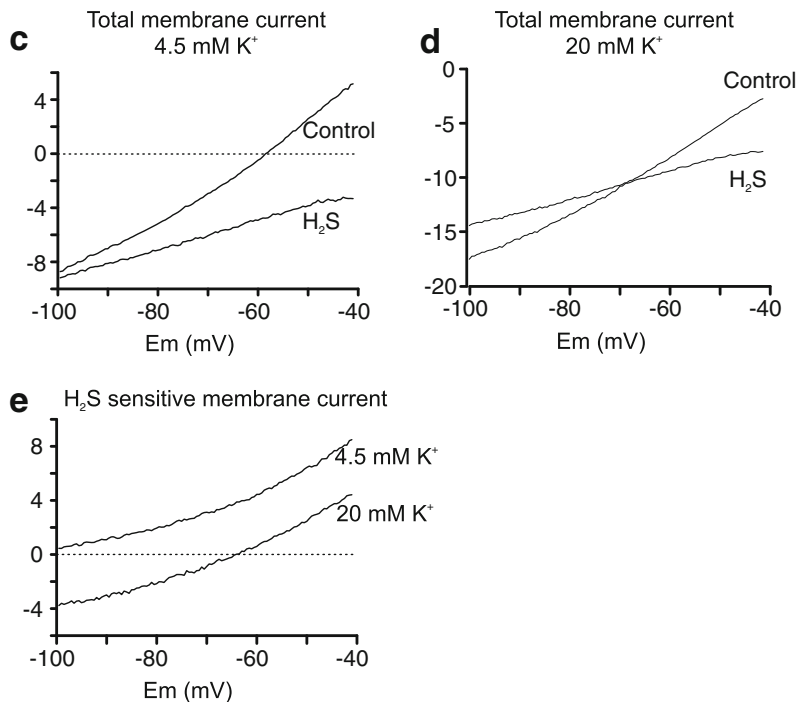

recording of type 1 cell autofluorescence and the effects of varying levels of $\mathrm{H}_{2} \mathrm{~S}$ upon it. $\mathrm{H}_{2} \mathrm{~S}$ causes a rapid and reversible increase in cellular autofluorescence $(p<0.001, n=$ 7). This effect was significant at concentrations of $2.5 \mu \mathrm{M}$ and above. The dose-response relation was well described by a four-parameter logistic curve (see "Methods" section) with an $\mathrm{EC}_{50}$ of $2.8 \mu \mathrm{M}$ (Fig. $6 \mathrm{c}$ ).

Inhibition of oxidative phosphorylation can also lead to a decline in cellular ATP levels. Since ATP is a chelator of 
Fig. 5 Effects of $\mathrm{H}_{2} \mathrm{~S}$ on background $\mathrm{K}^{+}$channels. a Cell-attached patch recording of background $\mathrm{K}^{+}$channel activity in a type 1 cell. Upward deflections show channel opening and current flow into the cell (inward current). Cells were bathed in a $100-\mathrm{mM} \mathrm{K}^{+}$Tyrode (see "Methods" section). Pipette solution contained $140 \mathrm{mM} \mathrm{K}{ }^{+}$. Pipette potential was $+80 \mathrm{mV}$. Traces on the left are sections of recording obtained under control conditions, those on the right were obtained in the presence of $75 \mu \mathrm{M} \mathrm{H}_{2} \mathrm{~S}$. b Comparison of background $\mathrm{K}^{+}$channel activity in cell-attached patches (as above) under control conditions and in the presence of $75 \mu \mathrm{M}$ $\mathrm{H}_{2} \mathrm{~S} . n=6$ cells; $p$ value determined by paired $t$ test a

$4 \mathrm{pA}$
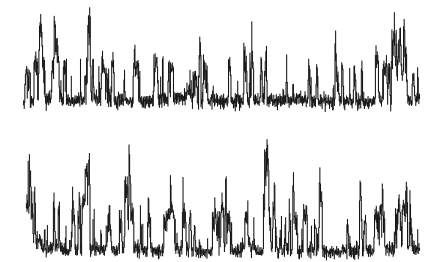

$75 \mu \mathrm{M} \mathrm{H}_{2} \mathrm{~S}$
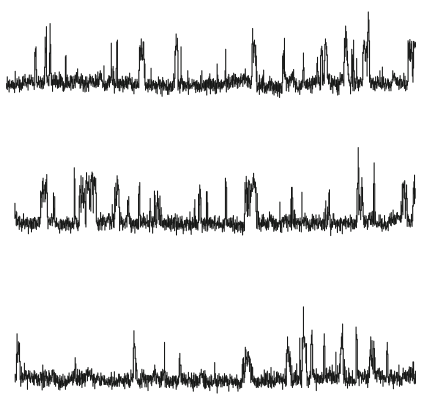

$\overline{20 \mathrm{msec}}$

b

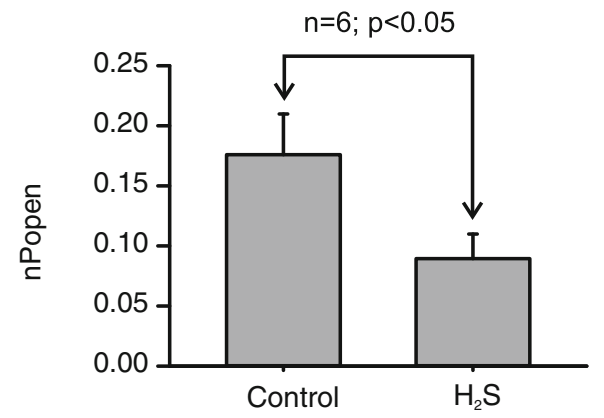

intracellular $\mathrm{Mg}^{+}$, a decline in ATP levels results in the release of $\mathrm{Mg}^{2+}$ into the cytosol. Under normal conditions, cellular levels of $\mathrm{Mg}^{2+}$ are relatively low, e.g. $0.3-1.25 \mathrm{mM}$ $[18,32,45]$, and although $\left[\mathrm{Mg}^{2+}\right]_{\mathrm{i}}$ is actively regulated, transmembrane fluxes are invariably slow $[15,42,43]$. As a consequence, resting $\left[\mathrm{Mg}^{2+}\right]_{\mathrm{i}}$ tends to be relatively constant. For the above levels of free $\mathrm{Mg}$, most ATP within the cell would be expected to be complexed with $\mathrm{Mg}^{2+}$, depletion of ATP by conversion first to ADP and then to AMP (by adenylate kinase) is therefore associated with the release of significant amounts of $\mathrm{Mg}^{2+}$ and a readily detectable rise in cytosolic $\left[\mathrm{Mg}^{2+}\right]_{\mathrm{i}}[14,19,30]$. Thus, ATP depletion can be followed by measuring $\left[\mathrm{Mg}^{2+}\right]_{\mathrm{i}}$. Rapid elevation of $\left[\mathrm{Mg}^{2+}\right]_{\mathrm{i}}$ has previously been reported to occur in type 1 cells following the application of many other inhibitors of oxidative phosphorylation including cyanide, rotenone, oligomycin and 2-4-dinitrophenol [48]. Figure 6b shows a recording of $\left[\mathrm{Mg}^{2+}\right]_{\mathrm{i}}$ in a type 1 cell using Mag-Indo-1. $\mathrm{H}_{2} \mathrm{~S}$ causes a reversible increase in $\left[\mathrm{Mg}^{2+}\right]_{\mathrm{i}}(p<0.001, n=9)$ as did another inhibitor of mitochondrial energy metabolism $1 \mu \mathrm{M}$ FCCP (Fig. 6b). This effect of $\mathrm{H}_{2} \mathrm{~S}$ was dose dependent; the rise in $\left[\mathrm{Mg}^{2+}\right]_{\mathrm{i}}$ was significant at $\mathrm{H}_{2} \mathrm{~S}$ concentrations of $\geq 7.5 \mu \mathrm{M}$, and the dose-response relationship was well described by a four-parameter logistic curve with an $\mathrm{EC}_{50}$ of $9.7 \mu \mathrm{M}$ (Fig. 6d).

A comparison of the concentration-dependent effects of $\mathrm{H}_{2} \mathrm{~S}$ on $\left[\mathrm{Ca}^{2+}\right]_{i}$, NADH levels and $\left[\mathrm{Mg}^{2+}\right]_{\mathrm{i}}$ is presented in Fig. 6e (with each dose-response curve normalised to a 0 $100 \%$ scale). It is apparent from these data that the dose dependency of the effects of $\mathrm{H}_{2} \mathrm{~S}$ upon type 1 cell $\left[\mathrm{Ca}^{2+}\right]_{\mathrm{i}}$ is comparable to the dose-dependent effects of $\mathrm{H}_{2} \mathrm{~S}$ on mitochondrial function in these cells.

Lack of additive effect of $\mathrm{H}_{2} \mathrm{~S}$ and other electron transport inhibitors on $\mathrm{K}_{\mathrm{B}}$ (TASK) channel activity

Given the similarity of the dose dependency of inhibition of mitochondrial function with that of excitation of the type 1 cell, and the previously well-described sensitivity of this tissue to excitation by other inhibitors of oxidative phosphorylation, the question arises as to whether $\mathrm{H}_{2} \mathrm{~S}$ can influence channel activity by any mechanism other than inhibition of mitochondrial function. To address this issue, the effects of $\mathrm{H}_{2} \mathrm{~S}$ were compared with those of another classical inhibitor of cytochrome oxidase, cyanide in single-channel recordings from the same cell-attached patches. Both compounds, at saturating levels (2 $\mathrm{mM} \mathrm{CN}^{-}$[54], $75 \mu \mathrm{M}$ $\mathrm{H}_{2} \mathrm{~S}$ ), caused a marked reduction in background (TASK) channel activity in cell-attached patches (Fig. 7a). The degree to which $\mathrm{H}_{2} \mathrm{~S}$ and $\mathrm{CN}^{-}$reduced channel open probability (NPopen, see "Methods" section) was similar at $74 \pm 3.4 \%$ and $68 \pm 5 \%$ (difference not significant). Combination of $\mathrm{H}_{2} \mathrm{~S}$ and $\mathrm{CN}^{-}$also reduced NPopen by $72 \pm 5.7 \%$ which was not significantly different from the effects of $\mathrm{CN}$ alone (Fig. $7 \mathrm{~b}, n=8$ patches). $\mathrm{H}_{2} \mathrm{~S}$ therefore had no additional effect on channel activity over that of cyanide. 
Fig. 6 Effects of $\mathrm{H}_{2} \mathrm{~S}$ on mitochondrial metabolism. a Measurement of cellular autofluorescence (excitation $340 \mathrm{nM}$, emission $450 \mathrm{nM}$ ) as an index of NADH levels. Upward deflection is consistent with increased NADH. Cell was bathed in normal Tyrode and subject to repeated 1-min exposures to $\mathrm{H}_{2} \mathrm{~S}$ in increasing concentrations. Note rapid increase in fluorescence/NADH at higher levels of $\mathrm{H}_{2} \mathrm{~S}$. b Measurement of free $\left[\mathrm{Mg}^{2+}\right]_{\mathrm{i}}$ using Mag-Indo-1. Increase in fluorescence ratio 405/495 denotes increase in free $\mathrm{Mg}^{2+}$. Increase in $\left[\mathrm{Mg}^{2+}\right]_{\mathrm{i}}$ indicates MgATP hydrolysis (see text). c Doseresponse plot for effects of $\mathrm{H}_{2} \mathrm{~S}$ on autofluorescence. Curve represents four-parameter logistic equation with an $\mathrm{EC}_{50}$ of $2.8 \mu \mathrm{M}$. Asterisks indicate data points significantly different from control (using HolmSidak method, see "Methods" section). d Dose-response plot for effects of $\mathrm{H}_{2} \mathrm{~S}$ on $\left[\mathrm{Mg}^{2+}\right]_{\mathrm{i}}$ (Mag-Indo-1 fluorescence ratio 405/495). Curve represents four-parameter logistic equation with an $\mathrm{EC}_{50}$ of $9.7 \mu \mathrm{M}$. Asterisks indicate data points significantly different from control (using Holm-Sidak method). e Comparison of dose-response data for effects of $\mathrm{H}_{2} \mathrm{~S}$ on $\left[\mathrm{Ca}^{2+}\right]_{\mathrm{i}},\left[\mathrm{Mg}^{2+}\right]_{\mathrm{i}}$ and NADH.

All data were normalised on a 0 (control) to $100 \%$ (maximum response) scale and curves recalculated using fourparameter logistic equations. Data points at $75 \mu \mathrm{M}$ are superimposed. Note proximity of both $\left[\mathrm{Ca}^{2+}\right]_{\mathrm{i}}$ and $\left[\mathrm{Mg}^{2+}\right]_{\mathrm{i}}$ responses with the NADH response displaced slightly to the left (lower $\mathrm{H}_{2} \mathrm{~S}$ concentrations)
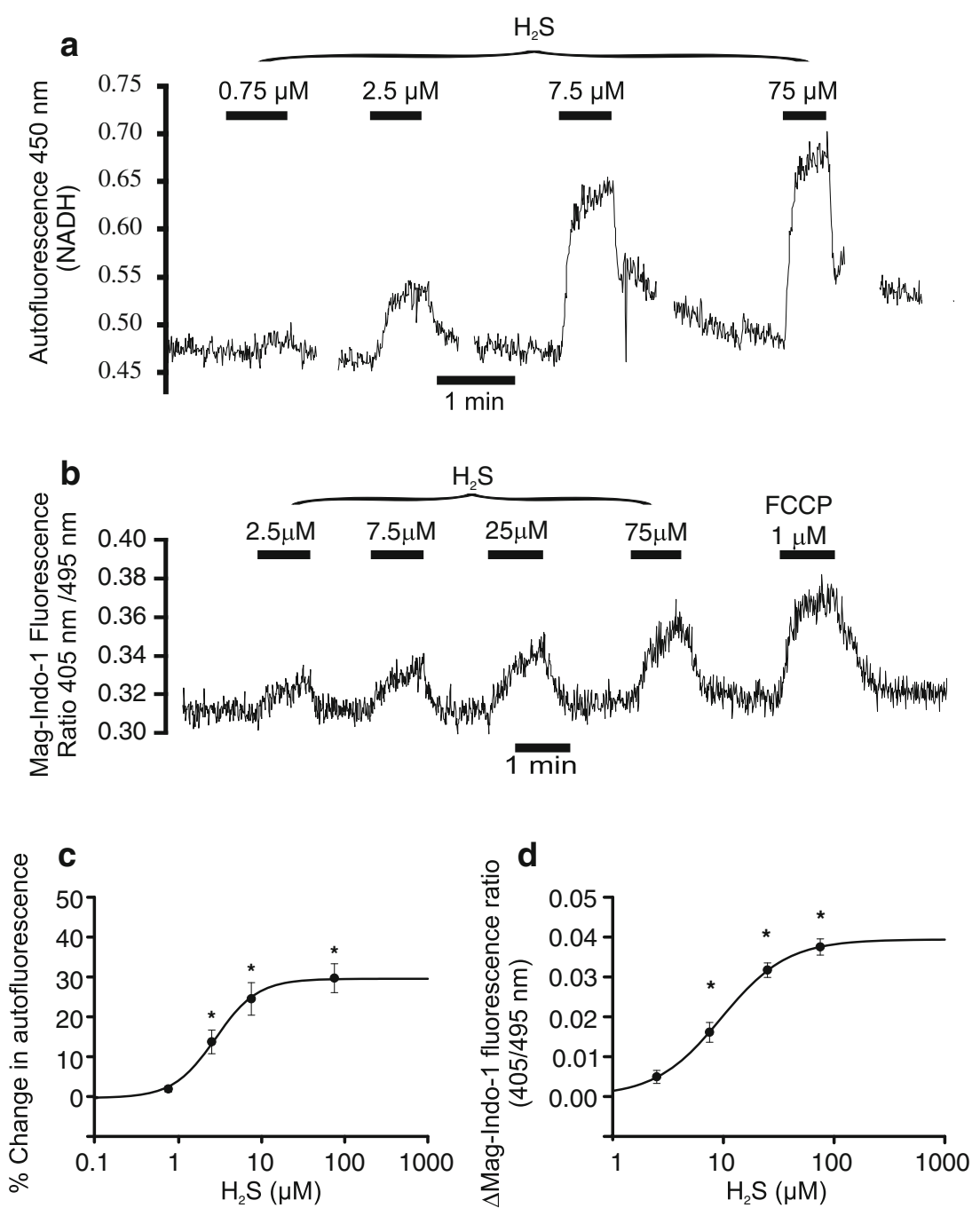

e

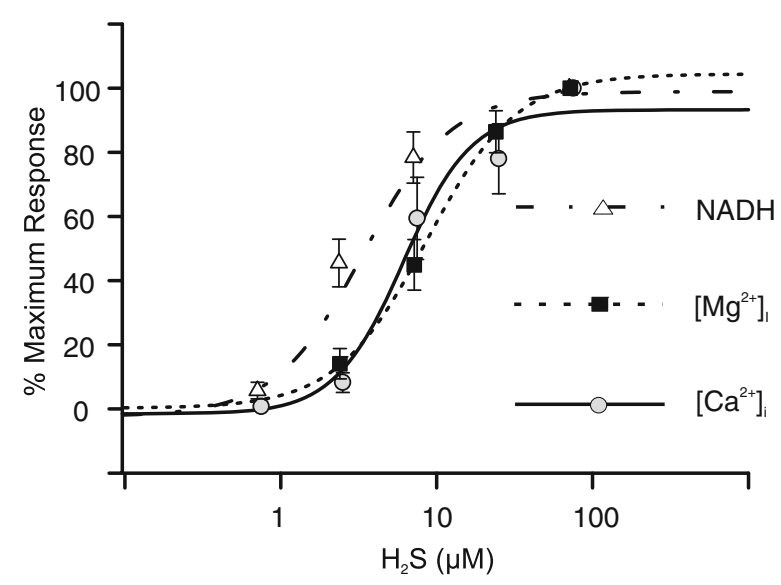

\section{Discussion}

Effects of $\mathrm{H}_{2} \mathrm{~S}$ on $\mathrm{Ca}^{2+}$ signalling in type 1 cells

Application of sulphide evoked an elevation of cytosolic calcium in all oxygen-sensitive type 1 cells studied. This effect was rapid in onset and also reversed rapidly upon removal of $\mathrm{H}_{2} \mathrm{~S}$. The $\mathrm{EC}_{50}$ for the $\mathrm{H}_{2} \mathrm{~S}$-evoked rise in $\left[\mathrm{Ca}^{2+}\right]_{\mathrm{i}}$ was estimated to be about $6 \mu \mathrm{M} \mathrm{H}_{2} \mathrm{~S}$. This calcium response was abolished by removal of extracellular calcium. These effects are comparable to the actions of sulphides on carotid sinus nerve (CSN) activity in isolated rat carotid body which 

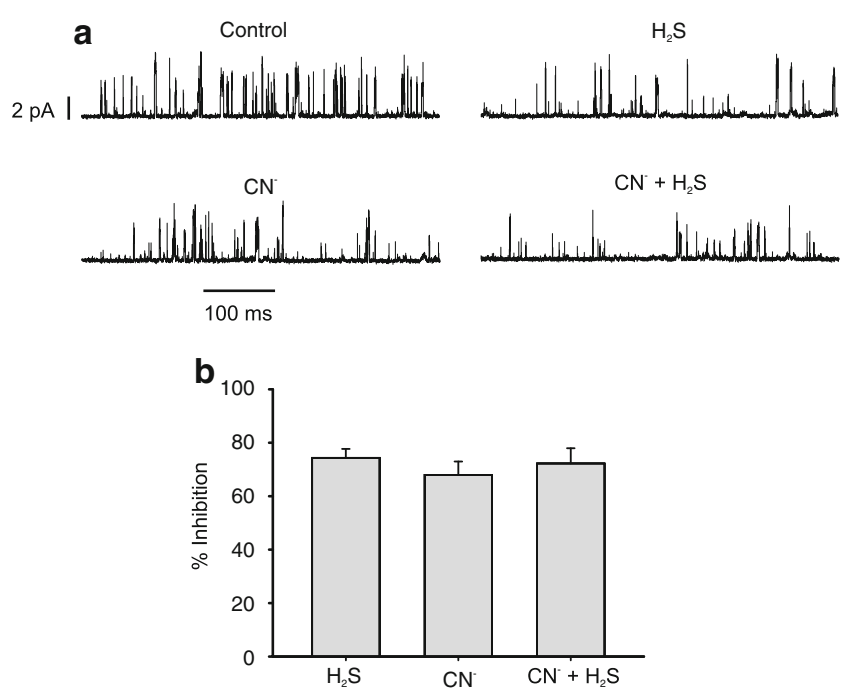

Fig. 7 Effects of cyanide and $\mathrm{H}_{2} \mathrm{~S}$ on background $\mathrm{K}$ channel activity. a Short sections of a cell-attached patch recording of background $\mathrm{K}^{+}$ channel activity in a type 1 cell. Upward deflections show channel opening and current flow into the cell (inward current). Cells were bathed in a 100-mM K ${ }^{+}$Tyrode (see "Methods" section). Pipette solution contained $140 \mathrm{mM} \mathrm{K}^{+}$. Pipette potential was $+80 \mathrm{mV}$. Traces show channel activity under control conditions, in the presence of $2 \mathrm{mM} \mathrm{CN}^{-}$, in the presence of $75 \mu \mathrm{M} \mathrm{H}_{2} \mathrm{~S}$ and in the presence of both $2 \mathrm{mM} \mathrm{CN}^{-}$and $75 \mu \mathrm{M} \mathrm{H}_{2} \mathrm{~S}$. b Comparison of inhibitory effects of $75 \mu \mathrm{M} \mathrm{H}_{2} \mathrm{~S}, 2 \mathrm{mM} \mathrm{CN}^{-}$and $75 \mu \mathrm{M} \mathrm{H}_{2} \mathrm{~S}$ plus $2 \mathrm{mM} \mathrm{CN}^{-}$on channel activity. Data are expressed as percent inhibition of NPopen in the presence of $\mathrm{CN}^{-}$and $\mathrm{H}_{2} \mathrm{~S}$ relative to control; $n=8$ cells/patches

is rapidly and reversibly excited by $30 \mu \mathrm{M}$ NaHS (approximately $7.5 \mu \mathrm{M} \mathrm{H} \mathrm{H}_{2} \mathrm{~S}$ ) and abolished by $\left[\mathrm{Ca}^{2+}\right]_{\mathrm{o}}$ removal [41]. The effects of sulphide on CSN discharge rate are also abolished by a combination of $\mathrm{P} 2 \mathrm{X}$ and nicotinic receptor antagonists [31]. Collectively, these data argue that the principal site of action of sulphide within the carotid body is presynaptic, i.e. at the type 1 cell, and that calcium signalling plays a prominent role in promoting this response.

Mechanisms of $\mathrm{H}_{2} \mathrm{~S}$ signalling and their similarity to hypoxia

The effects of hypoxia on isolated rat type 1 cells include inhibition of background potassium channels $\left(\mathrm{K}_{\mathrm{B}}\right)$ [4], which are thought to be derived from TASK1 and TASK3 with a possible preponderance of the heterodimeric form TASK1-TASK3 [10, 25, 52]), and inhibition of calciumactivated large-conductance potassium channels $\left(\mathrm{BK}_{\mathrm{Ca}}\right)$ [40]. The inhibition of $K_{B}$ (TASK) channels leads to membrane depolarisation since these channels provide the major resting potassium conductance which maintains the negative resting membrane potential. Upon $\mathrm{K}_{\mathrm{B}}$ channel inhibition other, as yet poorly defined, background inward currents depolarise the cell until the threshold for activation of voltage-gated calcium channels is reached. At this point,
$\mathrm{Ca}^{2+}$ floods into the cell, action potentials may be generated and other voltage-gated and $\mathrm{Ca}^{2+}$-activated channels may become active.

The effect of exogenous $\mathrm{H}_{2} \mathrm{~S}$, as described in this paper, is directly comparable to those described above for hypoxia, i.e. inhibition of $K_{B}$ (TASK) channels causing membrane depolarisation, electrical activity and voltage-gated $\mathrm{Ca}$ entry. Like hypoxia, $\mathrm{H}_{2} \mathrm{~S}$ has also been reported to inhibit $\mathrm{BK}_{\mathrm{Ca}}$ [47], although the inhibition of $\mathrm{BK}_{\mathrm{Ca}}$ seems to require much higher levels of $\mathrm{H}_{2} \mathrm{~S}$ than those needed to excite intact cells and tissues. In all major respects, therefore, exogenous $\mathrm{H}_{2} \mathrm{~S}$ mimics the effects of hypoxia. It is however by no means unique in this regard, other inhibitors of cytochrome oxidase including cyanide, azide and carbon monoxide similarly mimic the effects of hypoxia [2, 3, 20, 22, 53, 54].

\section{Effects of $\mathrm{H}_{2} \mathrm{~S}$ on mitochondrial function}

The similarity between the effects of $\mathrm{H}_{2} \mathrm{~S}$, hypoxia and other complex IV inhibitors raises the question as to whether the effects of $\mathrm{H}_{2} \mathrm{~S}$ can simply be attributed to inhibition of complex IV. To address this issue, it is pertinent to consider whether $\mathrm{H}_{2} \mathrm{~S}$ actually alters mitochondrial function over the range of concentrations for which it acts as a chemostimulant. Direct measurement of mitochondrial function in this tissue is not practical due to its small size; consequently, two indirect methods have been employed.

The first method measured NADH levels by its intrinsic fluorescence (NAD is not fluorescent). In short-term experiments, increase in autofluorescence indicates increase in NADH/NAD ratio which may arise from impaired NADH oxidation. The data (Fig. 6) show that $\mathrm{H}_{2} \mathrm{~S}$ is able to elevate $\mathrm{NADH}$ levels from quite low concentrations. There are, however, two distinct mechanisms by which $\mathrm{H}_{2} \mathrm{~S}$ could increase NADH. At low concentrations, $\mathrm{H}_{2} \mathrm{~S}$ is oxidised by mitochondrial sulphide quinione reductase (SQR) with concomitant reduction of ubiquinone [28]. The reduced ubiquinone is then oxidised by complex III of the electron transport chain. The oxidation of $\mathrm{H}_{2} \mathrm{~S}$ (by $\mathrm{SQR}$ ) could in principle compete with complex I for ubiquinone [28] if the flux of electrons through SQR is sufficient. Thus, low levels of $\mathrm{H}_{2} \mathrm{~S}$ might cause a small increase in NADH without compromising oxidative phosphorylation. At higher levels, however, the $\mathrm{H}_{2} \mathrm{~S}$-induced rise in NADH is most likely to be due to inhibition of electron transport.

The second method evaluated the effects of $\mathrm{H}_{2} \mathrm{~S}$ upon oxidative phosphorylation. This employs the measurement of free $\mathrm{Mg}^{2+}$ concentration within cells. Much of the $\mathrm{Mg}^{2+}$ within cells is bound to ATP, such that whenever there is net MgATP hydrolysis free $\mathrm{Mg}^{2+}$ is released into the cytosol and $\left[\mathrm{Mg}^{2+}\right]_{\mathrm{i}}$ increases (see e.g. $\left.[1,19,30]\right)$. These experiments were conducted in a Ca-free Tyrode to prevent $\mathrm{Ca}^{2+}$ influx during exposure to $\mathrm{H}_{2} \mathrm{~S}$ and possible interference 
with the Mag-Indo1 signal. The rise in $\left[\mathrm{Ca}^{2+}\right]_{\mathrm{i}}$ encountered under $\mathrm{Ca}_{\mathrm{o}}{ }^{2+}$-free conditions $(15 \mathrm{nM})$ is not expected to have any measureable effect on Mag-Indo fluorescence which has a $\mathrm{Kd}$ for $\mathrm{Ca}^{2+}$ of around $34 \mu \mathrm{M}$ [29]. $\mathrm{As}_{2} \mathrm{~S}$ is a weak acid, it could also influence intracellular $\mathrm{pH}$. The sensitivity of Mag-indo-1 to $\mathrm{pH}$ interference is however negligible between 7.2 and 7.0 [19], and the concentrations of $\mathrm{H}_{2} \mathrm{~S}$ employed even at the highest level $\left(75 \mu \mathrm{M} \mathrm{H}_{2} \mathrm{~S}, 300 \mu \mathrm{M}\right.$ total sulphide) are unlikely to cause an intracellular acidification of more than about $0.003 \mathrm{pH}$ units (assuming a total intrinsic [9] plus open system $\mathrm{HCO}_{3}{ }^{-} / \mathrm{CO}_{2}$ buffering capacity of $45 \mathrm{mM} / \mathrm{pH}$ at $\mathrm{pH}_{\mathrm{i}}=7.2$ ).

Measurements of $\left[\mathrm{Mg}^{2+}\right]_{\mathrm{i}}$ indicate that the dose-response curve for the effects of $\mathrm{H}_{2} \mathrm{~S}$ on MgATP is right shifted compared to the effects of $\mathrm{H}_{2} \mathrm{~S}$ on NADH levels (EC50 $=2.8 \mu \mathrm{M}$ for NADH and $9.7 \mu \mathrm{M}$ for $\left[\mathrm{Mg}^{2+}\right]_{\mathrm{i}}$ ). These data are compatible with the hypothesis that $\mathrm{H}_{2} \mathrm{~S}$ may serve as a substrate for electron transport at low levels and an inhibitor of electron transport and oxidative phosphorylation at higher levels. It may also simply reflect a greater sensitivity of NADH levels to inhibition of cytochrome oxidase activity.

Comparison of the effects of $\mathrm{H}_{2} \mathrm{~S}$ on $\left[\mathrm{Ca}^{2+}\right]_{i}$ with the above two indices of mitochondrial function revealed a particularly close correlation with the effects of $\mathrm{H}_{2} \mathrm{~S}$ on $\left[\mathrm{Mg}^{2+}\right]_{\mathrm{i}}$ indicating that the effects of $\mathrm{H}_{2} \mathrm{~S}$ on $\left[\mathrm{Ca}^{2+}\right]_{\mathrm{i}}$ may be linked to the decline in MgATP. The observations that the effects of $\mathrm{H}_{2} \mathrm{~S}$ on channel activity are similar to those of cyanide and that $\mathrm{H}_{2} \mathrm{~S}$ has no additional effect upon $\mathrm{K}_{\mathrm{B}}$ channel activity in the presence of cyanide (Fig. 7) support the conclusion that the actions of $\mathrm{H}_{2} \mathrm{~S}$ are primarily mediated via inhibition of oxidative phosphorylation. The mechanisms by which mitochondrial energy metabolism regulate $K_{B}$ channel function in type 1 cells have not yet been fully resolved, but two candidate pathways have been proposed; these are (1) direct modulation of the TASK channels by changes in MgATP levels [48] and (2) indirect modulation via changes in AMP/ATP levels and an AMP kinase [55]. Some questions have however been raised as to whether TASK channels can be directly modulated by AMP kinase [27].

In conclusion, the excitation of peripheral chemoreceptors by $\mathrm{H}_{2} \mathrm{~S}$ can be explained by $\mathrm{H}_{2} \mathrm{~S}$ 's ability to inhibit cytochrome oxidase and the type 1 cells widely reported sensitivity to anything that disrupts oxidative phosphorylation. There was no evidence for any significant involvement of nonmitochondrial signalling pathways in regulating $\mathrm{K}_{\mathrm{B}}$ channels or of effects of $\mathrm{H}_{2} \mathrm{~S}$ on $\left[\mathrm{Ca}^{2+}\right]_{i}$ at concentrations less than those which interfere with mitochondrial metabolism.

Role of $\mathrm{H}_{2} \mathrm{~S}$ in oxygen signalling

The above observations raise the question as to whether endogenous production of $\mathrm{H}_{2} \mathrm{~S}$ could nonetheless play a role in oxygen sensing via inhibition of complex IV. Such a hypothesis would be compatible with other current theories regarding oxygen sensing, metabolic signalling and ion channel regulation in type 1 cells $[48,55]$. It would also offer an alternative to cytochrome oxidase as the "oxygen sensor" in the form of sulphur dioxygenase. Serious concerns have however been expressed regarding levels of exogenous $\mathrm{H}_{2} \mathrm{~S}$ that appear to be required to excite chemoreceptors and whether similar levels could realistically be generated endogenously in vivo [17]. The same considerations must be applied to this study. In order to generate any reproducible $\left[\mathrm{Ca}^{2+}\right]_{\mathrm{i}}$ response, $\mathrm{H}_{2} \mathrm{~S}$ needed to be $>=2.5 \mu \mathrm{M}$; to generate a $\left[\mathrm{Ca}^{2+}\right]_{\mathrm{i}}$ response comparable to that seen with hypoxia (Fig. 1) required $>=7.5 \mu \mathrm{M} \mathrm{H}_{2} \mathrm{~S}$. The need for such high levels of $\mathrm{H}_{2} \mathrm{~S}$ to evoke even a small response represents a serious problem for the hypothesis that oxygen sensing is mediated via endogenous $\mathrm{H}_{2} \mathrm{~S}$ production. $\mathrm{H}_{2} \mathrm{~S}$ is highly membrane permeable (diffusion coefficient $=0.5 \mathrm{~cm} / \mathrm{s}$ [33]), isolated type 1 cells are small (approximately $5 \mu \mathrm{m}$ radius) and experiments are conducted in a fast flowing stream of saline which would prevent external $\mathrm{H}_{2} \mathrm{~S}$ accumulation. Under these conditions, an internal concentration of just $1 \mu \mathrm{M} \mathrm{H} \mathrm{H}_{2} \mathrm{~S}$ would drive a transmembrane $\mathrm{H}_{2} \mathrm{~S}$ efflux of $1.6 \mathrm{fM} / \mathrm{s}$ (calculated using Fick's first law of diffusion). For a type 1 cell to maintain an intracellular concentration of $1 \mu \mathrm{M}$, it would therefore need to continually generate $\mathrm{H}_{2} \mathrm{~S}$ at the same rate. For a $5-\mu \mathrm{m}$ radius cell, this would require $\mathrm{H}_{2} \mathrm{~S}$ synthesis at a rate equivalent to $180 \mathrm{mM} / \mathrm{min} / 1$ intracellular fluid. Estimates of the maximum capacity for tissues to generate $\mathrm{H}_{2} \mathrm{~S}$ vary. Liver homogenate (which appears to have one of the highest capacities for $\mathrm{H}_{2} \mathrm{~S}$ generation) can generate up to $1 \mathrm{mM} / \mathrm{min} / \mathrm{kg}$ tissue at saturating concentrations of cysteine/homocysteine [23], but with the use of physiologically relevant concentrations of substrate, this falls to only $8 \mu \mathrm{M} / \mathrm{min} / \mathrm{kg}$ liver tissue [49]. These rates are over two orders of magnitude less than that required to sustain a $1-\mu \mathrm{M}$ concentration gradient of $\mathrm{H}_{2} \mathrm{~S}$ across the membrane. The problem is not limited just to a consideration of the kinetics of $\mathrm{H}_{2} \mathrm{~S}$ production. There is an even more serious issue regarding the availability of substrate from which to synthesise $\mathrm{H}_{2} \mathrm{~S}$. Isolated type 1 cells can continue to respond to hypoxia for an hour or more whilst being maintained in just a simple saline. To continue to produce $\mathrm{H}_{2} \mathrm{~S}$ at the above rate for an hour would require a source of cysteine/homocysteine equivalent to 11 moles/l intracellular fluid. In contrast, tissue levels of homocysteine/cysteine are only in the region of $10-1,000 \mu \mathrm{M}$ [49]. In conclusion, if the reported values for lipid bilayer permeability to $\mathrm{H}_{2} \mathrm{~S}$ are correct, it is highly questionable whether endogenous $\mathrm{H}_{2} \mathrm{~S}$ could act as a freely diffusible signalling molecule operating at the micromolar level under the conditions typically used for studying oxygen sensing in isolated cells. 
Mitochondria and oxygen sensing

Finally, it should be noted that this study shows that yet another inhibitor of mitochondrial function mimics the effects of hypoxia in the type 1 cell. One of the most remarkable features of the carotid body is its extraordinary sensitivity to these agents and the fact that mitochondrial function in type 1 cells appears to be exceptionally sensitive to even moderate hypoxia $[11,12]$. It is tempting therefore to speculate that, even if $\mathrm{H}_{2} \mathrm{~S}$ does not act as a specific messenger in oxygen sensing, physiological levels of $\mathrm{H}_{2} \mathrm{~S}$ production together with other endogenous inhibitors of cytochrome oxidase, e.g. NO and $\mathrm{CO}$, might in some way contribute to the unusual oxygen sensitivity of mitochondrial function in these cells.

\section{Summary}

In summary, the following conclusions may be reached:

1. $\mathrm{H}_{2} \mathrm{~S}$ excites carotid body type 1 cells via inhibition of background $\mathrm{K}$-channels depolarisation and voltagegated $\mathrm{Ca}$ entry. These effects are qualitatively similar to those of hypoxia.

2. Background $\mathrm{K}$ channel inhibition by $\mathrm{H}_{2} \mathrm{~S}$ is probably secondary to inhibition of electron transport and oxidative phosphorylation.

3. There was no evidence for any effect of $\mathrm{H}_{2} \mathrm{~S}$ on type 1 cell $\left[\mathrm{Ca}^{2+}\right]_{\mathrm{i}}$ at levels less than those required to inhibit mitochondrial function nor was there any effect of $\mathrm{H}_{2} \mathrm{~S}$ on channel activity in the presence of cyanide. This would appear to rule out a significant role for any additional non-mitochondrial $\mathrm{H}_{2} \mathrm{~S}$ receptor-mediated signalling pathway.

4. The levels of $\mathrm{H}_{2} \mathrm{~S}$ required to excite type 1 cells via complex IV inhibition make this pathway an unlikely candidate for mediating the effects of hypoxia in isolated cells. A minor role for lower levels of $\mathrm{H}_{2} \mathrm{~S}$ in modulating mitochondrial $\mathrm{O}_{2}$ sensitivity cannot however be ruled out at this stage.

Open Access This article is distributed under the terms of the Creative Commons Attribution License which permits any use, distribution, and reproduction in any medium, provided the original author(s) and the source are credited.

\section{References}

1. Abramov AY, Duchen MR (2010) Impaired mitochondrial bioenergetics determines glutamate-induced delayed calcium deregulation in neurons. Biochim Biophys Acta 1800:297-304

2. Anichkov S, Belen'kii M (1963) Pharmacology of the carotid body chemoreceptors. Pergamon Press, Oxford

3. Barbe C, Al-Hashem F, Conway AF, Dubuis E, Vandier C, Kumar $\mathrm{P}$ (2002) A possible dual site of action for carbon monoxide- mediated chemoexcitation in the rat carotid body. J Physiol 543:933-945. doi:Electronic Resource Number

4. Buckler KJ (1997) A novel oxygen-sensitive potassium current in rat carotid body type I cells. J Physiol 498:649-662

5. Buckler KJ, Vaughan Jones RD (1993) Effects of acidic stimuli on intracellular calcium in isolated type I cells of the neonatal rat carotid body. Pflugers Arch 425:22-27

6. Buckler KJ, Vaughan Jones RD (1994) Effects of hypoxia on membrane potential and intracellular calcium in rat neonatal carotid body type I cells. J Physiol 476:423-428

7. Buckler KJ, Vaughan Jones RD (1994) Effects of hypercapnia on membrane potential and intracellular calcium in rat carotid body type I cells. J Physiol 478:157-171

8. Buckler KJ, Vaughan Jones RD (1998) Effects of mitochondrial uncouplers on intracellular calcium, $\mathrm{pH}$ and membrane potential in rat carotid body type I cells. J Physiol 513:819-833

9. Buckler KJ, Vaughan Jones RD, Peers C, Nye PC (1991) Intracellular $\mathrm{pH}$ and its regulation in isolated type I carotid body cells of the neonatal rat. J Physiol 436:107-129

10. Buckler KJ, Williams BA, Honore E (2000) An oxygen-, acid- and anaesthetic-sensitive TASK-like background potassium channel in rat arterial chemoreceptor cells. J Physiol 525(Pt 1):135-142

11. Duchen MR, Biscoe TJ (1992) Relative mitochondrial membrane potential and $[\mathrm{Ca} 2+] \mathrm{i}$ in type I cells isolated from the rabbit carotid body. J Physiol 450:33-61

12. Duchen MR, Biscoe TJ (1992) Mitochondrial function in type I cells isolated from rabbit arterial chemoreceptors. J Physiol 450:13-31

13. Erecinska M, Wilson DF (1981) Inhibitors of mitochondrial functions. Pergamon Press, Oxford

14. Grubbs RD (2002) Intracellular magnesium and magnesium buffering. Biometals 15:251-259

15. Grubbs RD, Collins SD, Maguire ME (1984) Differential compartmentation of magnesium and calcium in murine S49 lymphoma cells. J Biol Chem 259:12184-12192

16. Haggard HW, Henderson Y, Charlton TJ (1922) The influence of hydrogen sulfide upon respiration. Am J Physiol 61:289-297

17. Haouzi P, Bell H, Van de Louw A (2011) Hypoxia-induced arterial chemoreceptor stimulation and hydrogen sulfide: too much or too little? Respir Physiol Neurobiol 179:97-102

18. Harman AW, Nieminen AL, Lemasters JJ, Herman B (1990) Cytosolic free magnesium, ATP and blebbing during chemical hypoxia in cultured rat hepatocytes. Biochem Biophys Res Commun 170:477-483

19. Henrich M, Buckler KJ (2008) Effects of anoxia, aglycaemia and acidosis on cytosolic $\mathrm{Mg} 2+$, ATP and $\mathrm{pH}$ in rat sensory neurons. Am J Physiol Cell Physiol 294(1):C280-C294

20. Heymans C, Bouckaert JJ, Dautrebande L (1931) Sinus carotidien et reflexes respiratoires: sensibilite des sinus carotidiens aux substances chimiques. Action stimulante respiratoire reflexe du sulfure de sodium, du cyanure de potassium, de la nicotine et de la lobeline. Arch Int Pharmacodyn Ther 40:54-91

21. Hildebrandt TM, Grieshaber MK (2008) Three enzymatic activities catalyze the oxidation of sulfide to thiosulfate in mammalian and invertebrate mitochondria. FEBS J 275:3352-3361

22. Joels N, Neil E (1962) The action of high tensions of carbon monoxide on the carotid chemoreceptors. Arch Int Pharmacodyn Ther 139:528-534

23. Kabil O, Vitvitsky V, Xie P, Banerjee R (2011) The quantitative significance of the transsulfuration enzymes for $\mathrm{H}(2) \mathrm{S}$ production in murine tissues. Antioxid Redox Signal 15(2):363-372

24. Kamoun P (2004) Endogenous production of hydrogen sulfide in mammals. Amino Acids 26:243-254

25. Kim D, Cavanaugh EJ, Kim I, Carroll JL (2009) Heteromeric TASK-1/TASK-3 is the major oxygen-sensitive background $\mathrm{K}+$ channel in rat carotid body glomus cells. J Physiol 587:2963-2975

26. Kimura H (2011) Hydrogen sulfide: its production, release and functions. Amino Acids 41:113-121 
27. Kreneisz O, Benoit JP, Bayliss DA, Mulkey DK (2009) AMPactivated protein kinase inhibits TREK channels. J Physiol 587:5819-5830

28. Lagoutte E, Mimoun S, Andriamihaja M, Chaumontet C, Blachier F, Bouillaud F (2010) Oxidation of hydrogen sulfide remains a priority in mammalian cells and causes reverse electron transfer in colonocytes. Biochim Biophys Acta 1797:1500-1511

29. Lattanzio FA Jr, Bartschat DK (1991) The effect of $\mathrm{pH}$ on rate constants, ion selectivity and thermodynamic properties of fluorescent calcium and magnesium indicators. Biochem Biophys Res Commun 177:184-191

30. Leyssens A, Nowicky AV, Patterson L, Crompton M, Duchen MR (1996) The relationship between mitochondrial state, ATP hydrolysis, $\left[\mathrm{Mg}^{2+}\right]_{\mathrm{i}}$ and $\left[\mathrm{Ca}^{2+}\right]_{\mathrm{i}}$ studied in isolated rat cardiomyocytes. $\mathrm{J}$ Physiol 496(Pt 1):111-128

31. Li Q, Sun B, Wang X, Jin Z, Zhou Y, Dong L, Jiang LH, Rong W (2010) A crucial role for hydrogen sulfide in oxygen sensing via modulating large conductance calcium-activated potassium channels. Antioxid Redox Signal 12:1179-1189

32. Li-Smerin Y, Levitan ES, Johnson JW (2001) Free intracellular $\mathrm{Mg}^{2+}$ concentration and inhibition of NMDA responses in cultured rat neurons. J Physiol 533:729-743

33. Mathai JC, Missner A, Kugler P, Saparov SM, Zeidel ML, Lee JK, Pohl P (2009) No facilitator required for membrane transport of hydrogen sulfide. Proc Natl Acad Sci U S A 106:16633-16638

34. Mills E, Jobsis FF (1972) Mitochondrial respiratory chain of carotid body and chemoreceptor response to changes in oxygen tension. J Neurophysiol 35:405-428

35. National Research Council (U.S.), Committee on Medical and Biologic Effects of Environmental Pollutants, Subcommittee on Hydrogen Sulfide (1979) Hydrogen sulfide. University Park Press, Baltimore

36. Olson KR, Whitfield NL (2010) Hydrogen sulfide and oxygen sensing in the cardiovascular system. Antioxid Redox Signal 12:1219-1234

37. Olson KR (2011) Hydrogen sulfide is an oxygen sensor in the carotid body. Respir Physiol Neurobiol 179(2-3):103-110

38. Olson KR, Dombkowski RA, Russell MJ, Doellman MM, Head SK, Whitfield NL, Madden JA (2006) Hydrogen sulfide as an oxygen sensor/transducer in vertebrate hypoxic vasoconstriction and hypoxic vasodilation. J Exp Biol 209:4011-4023

39. Olson KR, Healy MJ, Qin Z, Skovgaard N, Vulesevic B, Duff DW, Whitfield NL, Yang G, Wang R, Perry SF (2008) Hydrogen sulfide as an oxygen sensor in trout gill chemoreceptors. Am J Physiol Regul Integr Comp Physiol 295:R669-R680

40. Peers C (1990) Hypoxic suppression of $\mathrm{K}+$ currents in type I carotid body cells: selective effect on the $\mathrm{Ca} 2(+)$-activated $\mathrm{K}+$ current. Neurosci Lett 119:253-256

41. Peng YJ, Nanduri J, Raghuraman G, Souvannakitti D, Gadalla MM, Kumar GK, Snyder SH, Prabhakar NR (2010) H2S mediates
O2 sensing in the carotid body. Proc Natl Acad Sci U S A 107:10719-10724

42. Rogers TA, Mahan PE (1959) Exchange of radioactive magnesium in the rat. Proc Soc Exp Biol Med 100:235-239

43. Romani AM, Scarpa A (2000) Regulation of cellular magnesium. Front Biosci 5:D720-D734

44. Shen TCR, Hauss WH (1939) Influence of dinitrophenol, dinitroortocresol and paranitrophenol upon the carotid sinus chemoreceptors of the dog. Arch Int Pharmacodyn Ther 63:251-258

45. Silverman HS, Di Lisa F, Hui RC, Miyata H, Sollott SJ, Hanford RG, Lakatta EG, Stern MD (1994) Regulation of intracellular free $\mathrm{Mg}^{2+}$ and contraction in single adult mammalian cardiac myocytes. Am J Physiol 266:C222-C233

46. Singh S, Banerjee R (2011) PLP-dependent H(2)S biogenesis. Biochim Biophys Acta 1814(11):1518-1527

47. Telezhkin V, Brazier SP, Cayzac SH, Wilkinson WJ, Riccardi D, Kemp PJ (2010) Mechanism of inhibition by hydrogen sulfide of native and recombinant BKCa channels. Respir Physiol Neurobiol 172:169-178

48. Varas R, Wyatt CN, Buckler KJ (2007) Modulation of TASK-like background potassium channels in rat arterial chemoreceptor cells by intracellular ATP and other nucleotides. J Physiol 583:521-536

49. Vitvitsky V, Kabil O, Banerjee R (2012) High turnover rates for hydrogen sulfide allow for rapid regulation of its tissue concentrations. Antioxid Redox Signal. doi:10.1089/ars.2011.4310

50. Wang R (2010) Hydrogen sulfide: the third gasotransmitter in biology and medicine. Antioxid Redox Signal 12:1061-1064

51. Whitfield NL, Kreimier EL, Verdial FC, Skovgaard N, Olson KR (2008) Reappraisal of H2S/sulfide concentration in vertebrate blood and its potential significance in ischemic preconditioning and vascular signaling. Am J Physiol Regul Integr Comp Physiol 294:R1930-R1937

52. Williams BA, Buckler KJ (2004) Biophysical properties and metabolic regulation of a TASK-like potassium channel in rat carotid body type 1 cells. Am J Physiol Lung Cell Mol Physiol 286:L221L230

53. Wilson DF, Mokashi A, Chugh D, Vinogradov S, Osanai S, Lahiri S (1994) The primary oxygen sensor of the cat carotid body is cytochrome a3 of the mitochondrial respiratory chain. FEBS Lett 351:370-374

54. Wyatt CN, Buckler KJ (2004) The effect of mitochondrial inhibitors on membrane currents in isolated neonatal rat carotid body type I cells. J Physiol 556:175-191

55. Wyatt CN, Mustard KJ, Pearson SA, Dallas ML, Atkinson L, Kumar P, Peers C, Hardie DG, Evans AM (2007) AMP-activated protein kinase mediates carotid body excitation by hypoxia. J Biol Chem 282:8092-8098

56. Zhao W, Zhang J, Lu Y, Wang R (2001) The vasorelaxant effect of $\mathrm{H}(2) \mathrm{S}$ as a novel endogenous gaseous K(ATP) channel opener. EMBO J 20:6008-6016 